\title{
Quantification of Picric Acid on Nanosphere Polypyrrole Modified Electrode by Stripping Voltammetry Method
}

\author{
R. Manikandan ${ }^{1,2}$, B. Kavitha ${ }^{4}$, S. Rani ${ }^{3}$, N. Senthil Kumar ${ }^{3, *}$ \\ ${ }^{1}$ ResearchScholar (Ph.D Chemistry),Research and Development Centre,Bharathiar University, Coimbatore \\ 641046, Tamilnadu, India. \\ ${ }^{2}$ P.R Engineering College, Thanjavur, Tamilnadu, India \\ ${ }^{3}$ Department of Chemistry, Arignar Anna Government Arts College, Cheyyar 604 407, Tiruvannamalai, \\ Tamilnadu, India. \\ ${ }^{4}$ Department of Chemistry, Sri Ranganathar Institute of Engineering and Technology, Athipalayam, \\ Coimbatore 641110, Tamilnadu, India.
}

*Corresponding author: N. Senthil Kumar, e-mail: nsk.nagai@gmail.com; mobile:+91 9943260525

Received July $10^{\text {th }}, 2018$; Accepted July $17^{\text {th }}, 2019$.

DOI: http://dx.doi.org/10.29356/jmcs.v63i4.628

\begin{abstract}
The electrochemical studies of picric acid were carried out in acidic, neutral and basic buffer media at bare glassy carbon (GC) and polypyrrole modified GC electrode. Cyclic Voltammogram (CV) of picric acid exhibited three reduction peaks at $-0.4,-0.8$ and $-1.5 \mathrm{~V}(v s . \mathrm{Ag} / \mathrm{AgCl})$ and two oxidation peaks at 0.8 and $1.4 \mathrm{~V}$ (vs. $\mathrm{Ag} / \mathrm{AgCl}$ ). Among the various $\mathrm{pH}$ studied, highly sensitive response was observed at $\mathrm{pH}$ 1.0. The effect of scan rate was studied between 25 and $500 \mathrm{mVs}^{-1}$ at the optimal $\mathrm{pH}$.CV results revealed the adsorption-controlled reaction at the electrode surface. The GC electrode was modified with polypyrrole conducting polymer film to enhance the electrocatalytic activity of the reductive species. Atomic force microscopy (AFM) images showed the nanosphere morphology of the polypyrrole film, which was coated uniformly on the electrode surface. Under optimum experimental conditions, the influence of concentration on the stripping signal was studied. The linear range of detection was found between $50 \mathrm{ppb}$ and $250 \mathrm{ppb}$ with the lower limit of detection of $10 \pm 3$ ppb.
\end{abstract}

Keywords: Picric acid; polypyrrole; AFM; stripping voltammetry.

Resumen. Los estudios electroquímicos del ácido pícrico se realizaron en medios amortiguados ácidos, neutros y alcalinos con un electrodo de carbono vítreo (GC) y de GC modificado con polipirrol (PP). El voltamperograma cíclico $(\mathrm{CV})$ del ácido pícrico mostró tres picos de reducción a $-0.4,-0.8$ y $-1.5 \mathrm{~V}$ (frente a $\mathrm{Ag} / \mathrm{AgCl}$ ) y dos picos de oxidación a 0.8 y $1.4 \mathrm{~V}$ (frente a $\mathrm{Ag} / \mathrm{AgCl}$ ). Entre los diversos valores de $\mathrm{pH}$ estudiados, se observó una respuesta altamente sensible a $\mathrm{pH}$ de 1.0. El efecto de la velocidad de barrido se estudió entre 25 y $500 \mathrm{mVs}^{-1}$ en el pH óptimo. Los resultados de $\mathrm{CV}$ revelaron que la reacción está controlada por adsorción en la superficie del electrodo. El electrodo de GC fue modificado con una película polimérica conductora de PP para mejorar la actividad electrocatalítica de las especies. Las imágenes de la microscopía de fuerza atómica (AFM) mostraron la morfología de la nanoesfera de la película de PP, que recubre uniformemente la superficie del electrodo. Bajo condiciones experimentales óptimas, se estudió la influencia de la concentración en la señal de stripping. El rango lineal de detección se encontró entre 50 ppb y 250 ppb con el límite inferior de detección de $10 \pm 3 \mathrm{ppb}$.

Palabras clave: Ácido picrico; polypyrrole; AFM; stripping voltammetry. 


\section{Introduction}

In the past decades, various approaches have been explored to quantify the picric acid effluents, such as fluorimetry, chemical methods, capillary electrophoresis and spectrophotometry [1-5]. Venkatramaiah et al., have successfully developed a fluorescent chemosensor based on fluoranthene for the detection of picric acid, in which static fluorescence quenching is the dominant process by intercalative interactions between fluoranthene and nitroaromatics [6]. Junqueira et al., have reported an electrochemical method for quantitative analysis of picric acid explosive based on its electrochemical reduction at copper surfaces [7]. Parham et al., have reported a spectrophotometric method for removal, preconcentration and determination of trace amounts of picric acid in water samples [8]. Picric acid, one of the phenols, will do massive damages to human eyes, skin and respiratory systems [9]. The detection of picric acid is of great importance because a large amount of industries such as organic synthesis and drugs analysis all inevitably involve picric acid [10], which imposes severe risks on human health and the environment.As a consequence, many efforts have been devoted to the development of efficient technologies for the determination of picric acid in the environment.Several analytical methods have been developed for determining picric acid such as spectrophotometric [11], fluorescence [12,13], mass spectrometry [14,15], high-performance liquid chromatography [16], extraction [17], capillary electrophoresis [18], and electrochemical methods [19-22]. Compared to the above-mentioned methods, electrochemical techniques have advantages such as simplicity, selectivity, rapidity, low cost and easy miniaturization $[23,24]$.

Stable aqueous dispersions of Gold-polyaniline (GN-PANI) nanocomposites were used an interfacial polymerization approach. It is found that PANI can be coated on the surface of GN uniformly. The obtained GN-PANI nanocomposites act as a p-donor sites that combine 2,4,6-trinitrotoluene (TNT).In addition to the association of TNT to the p-donor sites, the formation of imprinted p-donor molecular contours around the complex might synergistically bind TNT analyte to the sensing surface, thus increasing the association constant $[25,26]$. Platinum nanoparticles-reduced graphene oxide composite-modified glassy carbon electrode as developed as a simple, selective and sensitive electrochemical sensor for determination of picric acid [27]. A simple and fast electrochemical method for quantitative analysis of picric acid explosive based on its electrochemical reduction at copper surfaces is reported. To achieve a higher sample throughout, the electrochemical sensor was adapted in a flow injection system [28].

In the present work, the advantages of electrocatalytic activities of polymer to modify glassy carbon electrodes are exploited. The glassy carbonelectrode (GCE) was modified by polypyrrole and used as a simple, selective and sensitive electrochemical sensor for the determination of picric acid. All the experimental parameters were optimized to achieve significant analytical figures of merit and to improve selectivity for the determination of picric acid.

\section{Experimental}

Pyrrole, $\mathrm{HClO}_{4}$, potassium carbonate and picric acid were purchased from e-Merck. The monomer was purified by distillation under nitrogen atmosphere before use, stored at $4{ }^{\circ} \mathrm{C}$ and protected from sun light. All other reagents were of analytical grade and were used without further purification. All solutions were prepared using deionized water. All experiments were carried out at ambient temperature. The $\mathrm{pH}$ values of the buffer solutions were measured by Hanna HI 2211 pH/ORP meter.

All electrochemical measurements were carried out with an electrochemical workstation (CHI 650C). The electrochemical cell contains a three-electrode system, a $0.34 \mathrm{~mm}$ glassy carbon electrode (GCE) as the working electrode, $\mathrm{Ag} / \mathrm{AgCl}$ as the reference electrode, and a platinum wire as the counter electrode. All the electrochemical measurements were performed in aqueous medium and hence no ohmic drop corrections were made. Atomic force microscope (AFM) was used to characterize the polymer and compound adsorbed surface (Nanosurf Easyscan 2, Switzerland). 


\section{Fabrication of polypyrrole (PPy) modified electrodes}

Before polymerization conducted, electrolyte solutions were deaerated thoroughly with pure nitrogen $(99 \% \mathrm{v} / \mathrm{v})$. The pyrrole polymerization was conducted potentiostatically by applying $0.85 \mathrm{~V} v s . \mathrm{Ag} / \mathrm{AgCl}$ in aqueous solution containing $0.15 \mathrm{M}$ pyrrole in $0.1 \mathrm{M} \mathrm{LiClO}_{4}$ and $0.1 \mathrm{M}$ potassium carbonate solution. Freshly prepared PPy electrodes were usually conditioned in $0.1 \mathrm{M} \mathrm{HClO}_{4}$ solution for 24 hours to remove the carbonate ions.

\section{Results and discussion}

\section{Fabrication of PPy modified GCE}

The PPy modified GC electrodes were fabricated as detailed in the experimental section. Impedance spectroscopy is used to evaluate the interfacial electrical properties of modified surface. Fig. 1 shows the impedance spectra recorded at bare GC and PPy modified GC electrodes. It is apparent from the surface modification clearly influences the impedance behavior. Modification with conducting PPy films created an increase in impedance due to double layer capacitance. The surface bound polymer film acts as capacitors they form a double layer around the surface.

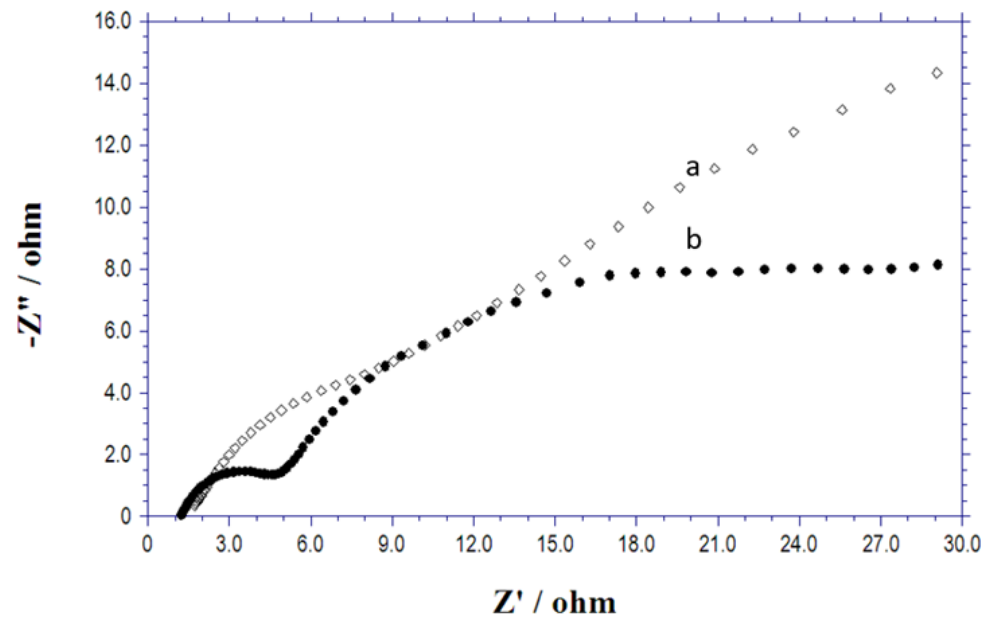

Fig. 1. Impedance spectra of (a) bare GCE and (b) PPy modified GCE applied frequency from 0.1 to 100 $\mathrm{KHz}$ and initial potential $0.5 \mathrm{~V}$

\section{Cyclic voltammetric behavior of picric acid}

Picric acid (IUPAC name: 2,4,6-trinitrophenol) is a yellow crystalline solid is one of the most acidic phenols. Initially, the electrochemical studies of $100 \mathrm{ppb}$ picric acid were carried out in acidic (acetate buffer), neutral (BR buffer) and basic (phosphate buffer) media at bare GC and PPy electrodes. Among the various $\mathrm{pH}$ studied, highly sensitive reduction respond was observed at $\mathrm{pH} 1.0$ (Fig. 2). This $\mathrm{pH}$ medium was used for further studies of detection of picric acid. 


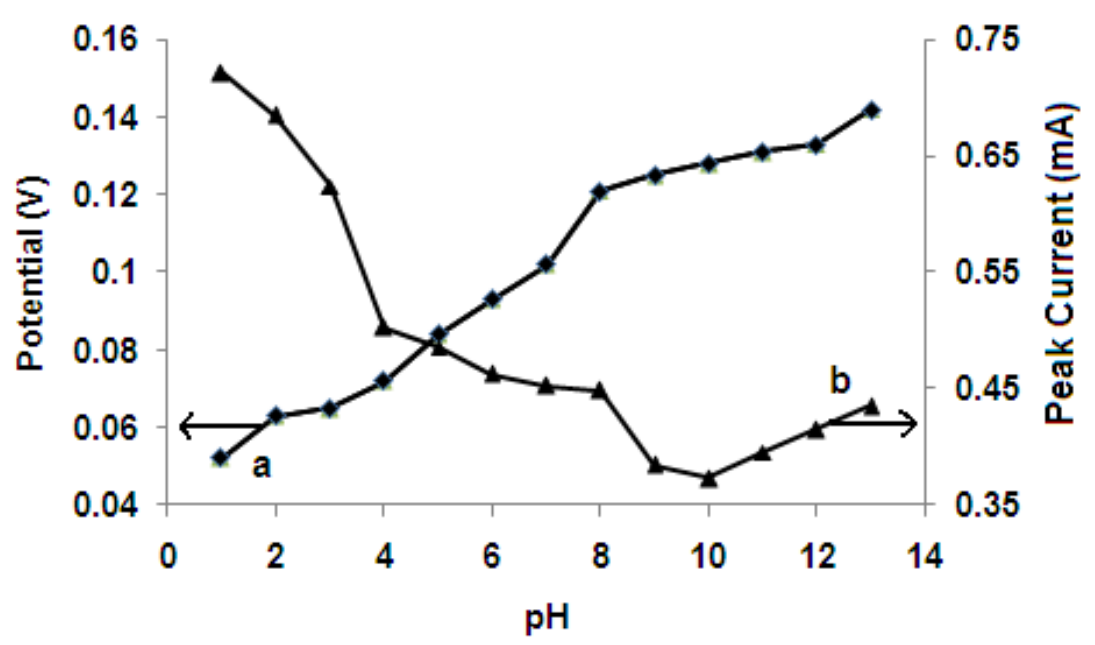

Fig. 2. Plots of (a) peak potential and (b) peak current vs. pH.

Fig. 3 (curves a and b) shows CV curves recorded on GCE and PPy in the acidic medium (pH1.0) containing $100 \mathrm{ppb}$ picric acid. The curve obtained under the same conditions at GCE and Ppy but without picric acid is also shown in Fig. 3 (curves $\mathrm{c}$ and d). During voltammetric cathodic scan, picric acid showed three reduction peaks at $-0.4,-0.8$ and $-1.5 \mathrm{~V}$ which corresponds to the reduction of $-\mathrm{NO}_{2}$ groups in picric acid. On the other hand, two peaks were observed during anodic scan at 0.8 and $1.2 \mathrm{~V}$. Both anodic and cathodic peaks were observed at all pHs. The reduction peaks were more sensitive than the anodic peaks. This may be due to the fact that the anodic oxidation of picric acid is more difficult than that of mono and di substituted phenols with amino, chloro and hydroxyl groups. These results can be explained by the withdrawing effect of the nitro groups which deactivate the aromatic ring.

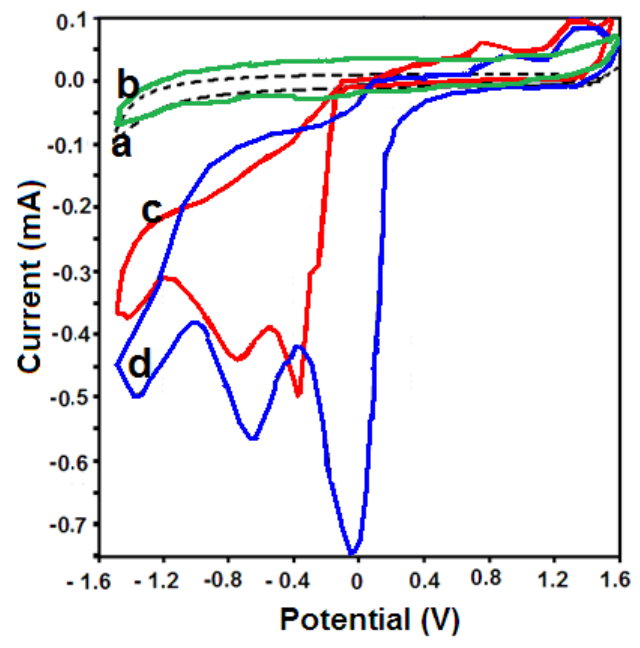

Fig. 3. Cyclic voltammograms recorded in the absence of picric acid (a) on glassy carbon electrode (b) polypyrrol modified GCE (c) in the presence of $100 \mathrm{ppb}$ picric acid at bare GCE, (d) in the presence of 100 ppb picric acid at Ppy modified GCE (pH1.0, scan rate: $50 \mathrm{mV} . \mathrm{s}^{-1}$ ). 
Electrochemical reduction of picric acid is pronounced (high peak current) at PPy modified GCE, probably due to the increase in the surface area and electrochemical activity compared to bare GCE (Fig. 3). The increase in electrochemical activity appear to have originated by deposition of polymeric adhesive products on the electrode surface. After completion of each measurement, the electrode was washed with ethanol to remove any adsorbed molecules. Further, the activity of the polymer surface is retained by performing an anodic polarization process in the same electrolyte at high potential.

The effect of scan rate was studied in between scan rates 25 and $500 \mathrm{mVs}^{-1}$ at $\mathrm{pH} 1.0$. A linear relationship between peak current and scan rate was observed (Fig. 4). Similarly, the influence of concentration was also studied. These results indicated that the overall reduction process of picric acid is adsorption-controlled reaction. The possible electrochemical reaction in acidic $\mathrm{pH}$ is proposed.

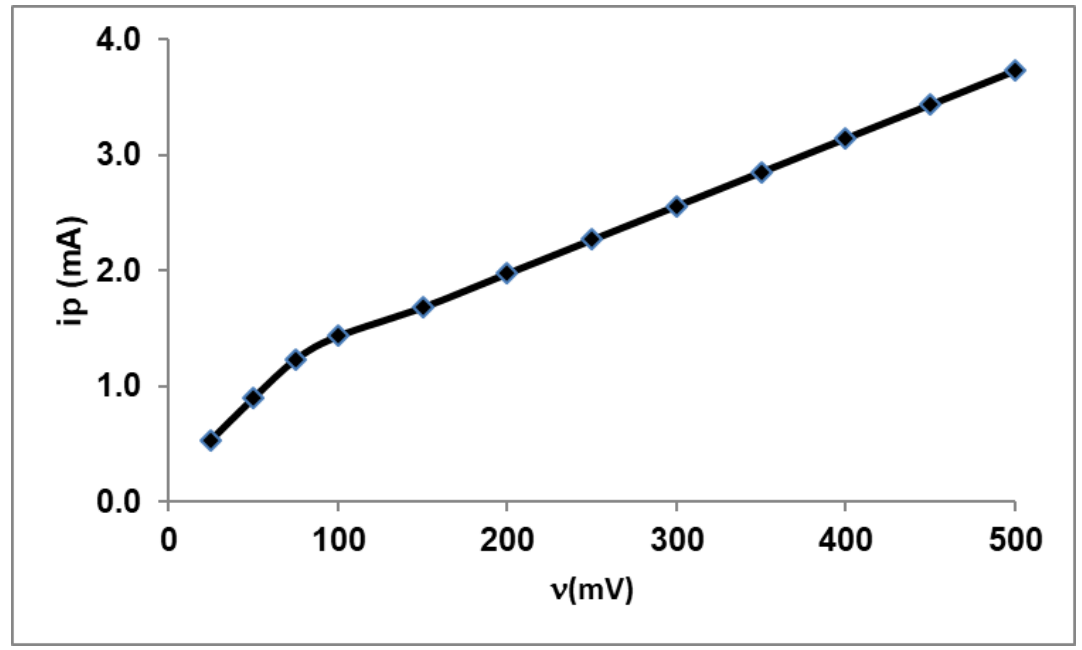

Fig. 4. Plot of peak current vs different scan rate of $100 \mathrm{ppb}$ picric acid on Ppy modified GCE at pH1.0

\section{Differential pulse stripping voltammetry}

Further, the GC electrode was modified with PPy film to enhance the electrocatalytic activity of the reductive process. This could be achieved due to high electronic conductivity of PPy which arises from the delocalized electrons in the polymer chain. Conducting polymers possess electrocatalytic effects leading to a decrease of the overpotential, increasing the reaction rate and sensitivity [29, 30].

Fig. 5 shows the 2D and 3D surface morphologies of PPy modified electrode, picric acid adsorbed surface, particle distribution graphs and surface roughness values. The polymer film is uniformly coated on the electrode surface and forms nanosphere morphology. The picric acid adsorbed surface exhibits similar morphological characteristics.

The stripping voltammetry studies were performed at bare GCE and PPy modified GCE in pH 1.0 solution using differential pulse stripping voltammetry method. The voltammetric results revealed the adsorption-controlled of the substrate on PPy modified GCE. Picric acid is adsorbed on the electrode surface during the accumulation step and stripped off during the stripping step. A systematic study of various instrumental parameters that affect the stripping responses has been carried out with $100 \mathrm{ppb}$ picric acid to establish the optimum conditions. Table 1 shows the data obtained during the optimization of experimental conditions to achieve sensitive response of picric acid at PPy modified GCE.

The accumulation potential $\left(E_{a c c}\right)$ was varied between 400 and $-800 \mathrm{mV}$ at an accumulation (deposition) time of $15 \mathrm{~s}$. Maximum Peak current was observed at $-400 \mathrm{mV}$ and it was fixed as the optimum accumulation potential. By varying the deposition time from 15 to $120 \mathrm{~s}$, the effect of deposition time was 
studied after fixing the deposition potential at $-400 \mathrm{mV}$. The highest current is observed at $15 \mathrm{~s}$ deposition time. Hence this is taken for the further experiment consideration.

The initial scanning potential is another important parameter as it confirms the non-faradaic nature of the pre-concentration step. It also controls both the peak potential and peak current in the stripping voltammogram. The influence of the initial potential on the peak current was studied by varying the initial scan potential from 600 to $200 \mathrm{mV}$. The peak current is affected by this initial potential in a different way. Better response i.e., high peak current with better resolution was observed at $500 \mathrm{mV}$. Effect of pulse height was studied by varying from 25 to $150 \mathrm{mV}$. The sharp peak current was observed at the pulse height of $100 \mathrm{mV}$. Similar to pulse height, pulse width also studied by varying from 25 to $150 \mathrm{~ms}$. The sharp peak nature with higher current was observed at pulse width of $100 \mathrm{~ms}$. Hence the pulse width of $100 \mathrm{~ms}$ was chosen as optimum value.
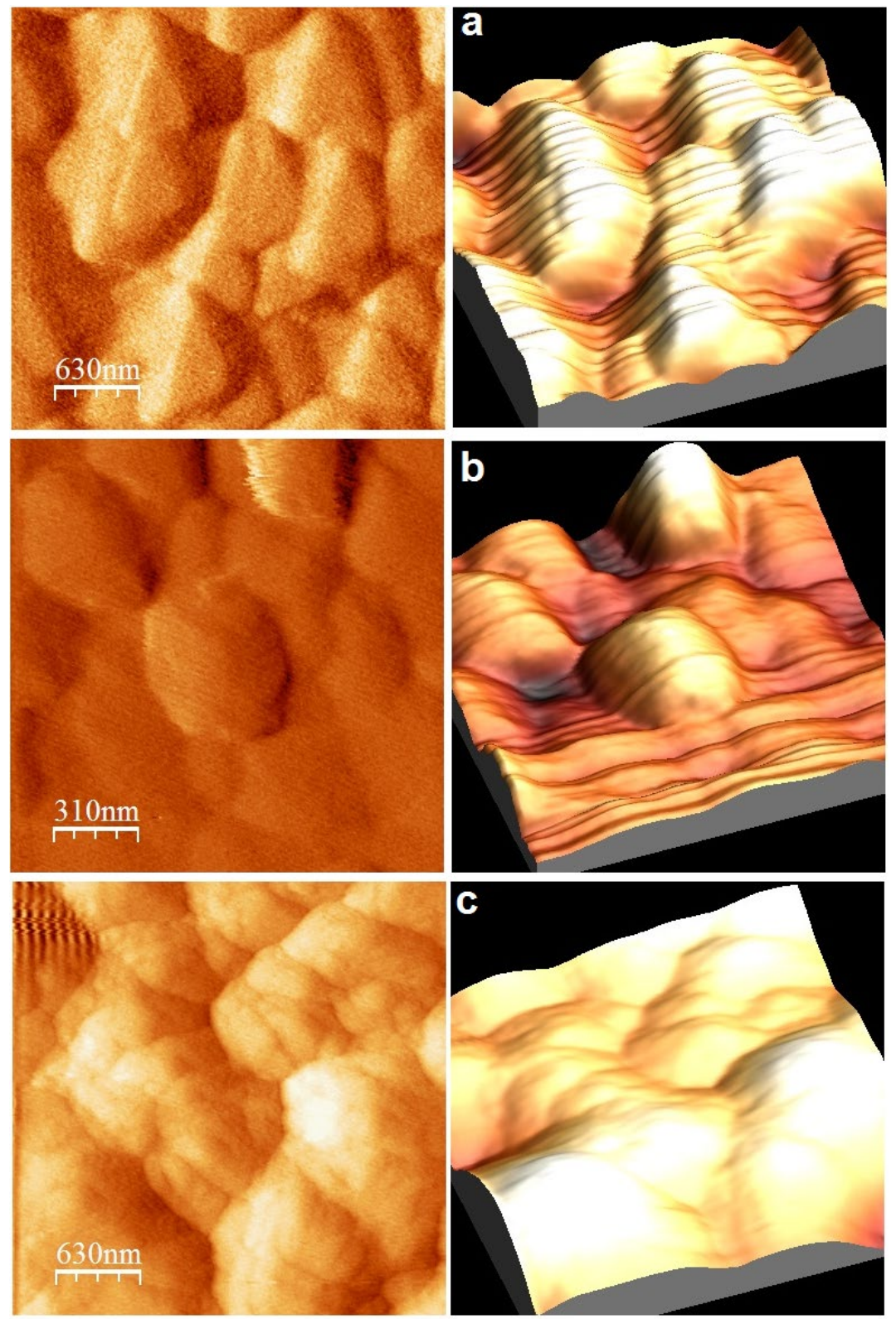

Fig. 5. AFM image of a) GCE b) Ppy/GCE c) picric acid adsorbed Ppy/GCE. 
The scan increment was varied between 4 to $16 \mathrm{mV}$ and maximum peak current response was obtained at $8 \mathrm{mV}$ scan increment. A study on the effect of pulse period in the range between 2 and $10 \mathrm{~s}$ was carried out. The stripping voltammetry signal showed the maximum peak current at $6 \mathrm{~s}$. The optimum conditions that resulted in highly sensitive response were used to study the effect of analyte concentration. The range of study and the optimum values are arrived and used for determination of picric acid (Table 1).

Table 1. AFM behaviour roughness value of different electrode surface.

\begin{tabular}{|c|c|c|c|}
\hline Parameter & GCE & Ppy/GCE & $\begin{array}{c}\text { Picric acid } \\
\text { adsorbed } \\
\text { Ppy/GCE }\end{array}$ \\
\hline Area $\left(\mathrm{pm}^{2}\right)$ & 2.461 & 2.461 & 2.461 \\
\hline Roughness Average $\left(\mathrm{S}_{\mathrm{a}}\right)(\mathrm{nm})$ & 17.415 & 29.152 & 29.503 \\
\hline Root mean square $\left(\mathrm{S}_{\mathrm{q}}\right)(\mathrm{nm})$ & 21.812 & 24.200 & 36.222 \\
\hline Peak-valley height $\left(\mathrm{S}_{\mathrm{y}}\right)(\mathrm{nm})$ & 121.231 & 151.920 & 234.241 \\
\hline Peak height $\left(\mathrm{S}_{\mathrm{p}}\right)(\mathrm{nm})$ & 73.033 & 83.653 & 96.263 \\
\hline Valley depth $\left(\mathrm{S}_{\mathrm{v}}\right)(\mathrm{nm})$ & -48.295 & -68.262 & -87.474 \\
\hline Mean value $\left(\mathrm{S}_{\mathrm{m}}\right)(\mathrm{fm})$ & -20.471 & -20.471 & -20.471 \\
\hline
\end{tabular}

\section{Analytical characteristics}

Under optimum experimental conditions, the influence of concentration on the stripping signal was studied. A representative differential stripping voltammogram is shown in Fig. 6. A linear response between the peak current and the concentration of picric acid is obtained (Fig. 7). The linear range of determination was found between $50 \mathrm{ppb}$ and $250 \mathrm{ppb}$. The precision was evaluated from seven replicate measurements of picric acid standard containing 100, 150 and $200 \mathrm{ppb}$, yielding a peak area RSD of 2.1, 2.3, 4.2\%, respectively. The Method detection limit, $\mathrm{S} / \mathrm{N}>3$, was determined to be $10 \pm 3 \mathrm{ppb}(\mathrm{CI}>95 \%)$. Noise is variation of the baseline current for a blank solution.

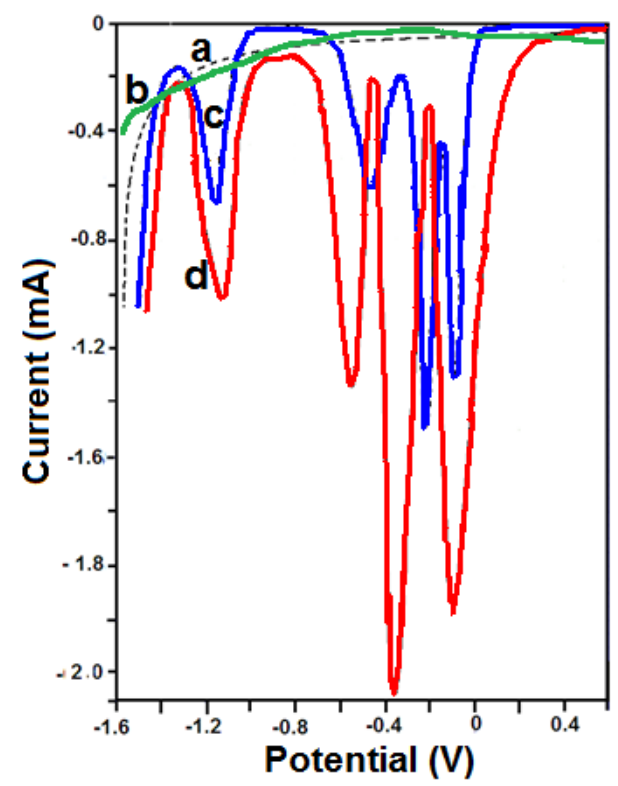

Fig. 6. Differential pulse voltammetry behavior of a) GCE, b) Ppy/GCE c) 100 ppb picric acid on GCE and d) $100 \mathrm{ppb}$ picric acid on Ppy/GCE at pH 1.0 Accumulation potential $-400 \mathrm{mV}$, Deposit time $15 \mathrm{~s}$, Initial scan potential $500 \mathrm{mV}$, Pulse Height and Pulse width $100 \mathrm{mV}$, Scan Increment $8 \mathrm{~ms}$, Scan rate $100 \mathrm{mV} / \mathrm{s}$. 


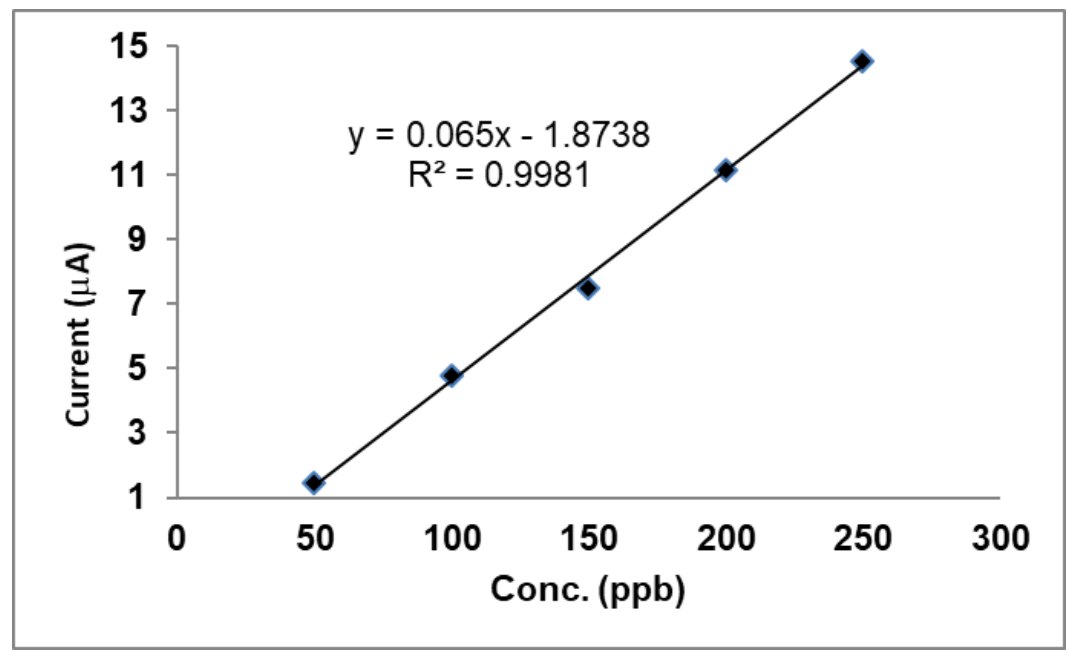

Fig. 7. Calibration plot obtained from stripping voltammetry measurement for the detection of picric acid at PPy modified GCE at $\mathrm{pH} 1.0$

\section{Conclusion}

The PPy modified electrode was successfully fabricated using electrochemical method and analytical properties towards the detection of picric acid using stripping voltammetry was explored. The PPy film presented a uniform nanospherical structure and possessed a better stability and higher sensitivity. Compared with a bare GC electrode, the PPy modified electrode greatly improved the sensitivity for the detection of picric acid at very low concentrations. The electrode conducted sensitive detection of picric acid within the concentration between 50 and $250 \mathrm{ppb}$, and the limit of detection was $10 \pm 3 \mathrm{ppb}(\mathrm{S} / \mathrm{N}=3)$.

\section{References}

1. Barek, J.; Fischer, J.; Wang. J. Vol. 6 (K. Kalcher, R. Metelka, I. Švancara, K. Vytas; Eds.), pp. 139147. (C) 2011 University Press Centre, Pardubice, Czech Republic. ISBN 978-80-7395-434-5 (printed); $978-$ 80-7395-435-2 (on-line)

2. Ibrahim, A.A.; Tiwari, P.; Al-Assiri, M.S.; Al-Salami, A.E.; Umar, A; Kumar, R.; Kim, S.H.; Ansari, Z.A.;Baskoutas, S. Materials. 2017, 795, 1-15

3. Vit Prchal; Vlastimil Vyskocil; Jiri Barek, Journal of the ElectrochemicalSociety. 2017, 164, H316H320

4. Caygill, J.S.; Davis, F.; Higson, S.P.J. Talanta. 2012, 88, 14-29

5. Peng, Y.; Zhang, A-J.; Dong, M.; Wang, Y-W. Chemical Communication. 2011, 47, 4505-4507

6. Venkatramaiah, N.; Kumar, S.; Patil, S. ChemicalComunicación2012, 48, 5007-5009

7. Junqueira, J.R.C.; de Araujo, W.R.; Salles, M.O.; Paixao, T.R.L.C. Talanta. 2013, 104, 162-168

8. Parham, H.;Zargar, B.;Rezazadeh, M. Materials Science and EngineeringC. 2012, 32, 2109-2114

9. Steuckart, C.;Prelss, E.B.;Levsen, K. Analytical Chemistry. 1994, 66, 2570-2577

10. Nipper, M.;Carr, R.S.;Biedenbach, J.M.; Hooten, R.L.; Miller, K.Marine Pollution Bulletin. 2005, 50, 1205-1217

11. Kojloa, A.;Karpinskab, J.;Kuzmickaa, L.;Misiuka, W.;Tarasiewicza, H.P.;Tarasiewicza, M. Trace and Microprobe Techniques. 2001, 19, 45-70

12. Üzer, A.;Erçağ, E.;Apak, R.Anal. Chim. Acta. 2004, 612, 53-64

13. Roy, B.; Bar, A.K.;Gole B.; Mukherjee, P.S.J. Org. Chem. 2013, 78, 1306-1310 
14. Bhalla, V.; Kaur, S.;Vij V.; Kumar, M. Inorg. Chem. 2013, 52, 4860-4865

15. Agarwal, B.; González-Méndez, R.; Lanza, M.; Sulzer, P.;Märk, T.D.; Thomas, N.; Mayhew, C.A.J. Phys. Chem. A. 2014, 118, 8229-8336

16. Ivanova, O.M.;Raks, V.A.; Zaitsev, V.N. J. Water Chem. Technol. 2014, 36, 273-279

17. Burdel, M.;Šandrejová, J.;Balogh, I.S.;Vishnikin, A.;Andruch, V. J. Sep, Sci. 2013, 36, 932-938

18. Cascio, O.;Trettene, M.;Bortolotti, F.;Milana, G.;Tagliaro, F. Electrophoresis. 2004, 25, 1543-1547

19. Vyskočil, V.;Navrátil, T.;Daňhel, A.;Dědík, J.;Krejčová, Z.;Škvorová, L.;Tvrdíková, J.;Barek, J.Electroanalysis. 2011, 23, 129-139

20. El Tall, O.;Beh, D.;Jaffrezic-Renault, N.;Vittori, O. Int. J. Environ. Anal. Chem. 2010, 90, 40-48

21. Huang, J.; Wang, L.; Shi, C.; Dai, Y.; Gu, C.; Liu, J. Sens. Actuators B: Chem. 2014, 196, 567-573

22. Giribabu, K.; Oh, S.Y.; Suresh, R.; Kumar, S.P.;Manigandan, R.;Munusamy, S.;Gnanamoorthy, G.;

Kim, J. Y.; Huh, Y.S.; Narayanan, V. Microchim. Acta. 2016, 183, 2421-2430

23. Jacobsen, M.;Duwensee, H.;Wachholz, F.;Adamovski, M.;Flechsig, G.U. Electroanalysis. 2010, 22, 1483-1488

24. Safavi, A.; Ahmadi, R.;Mahyari, F.A. Amino Acids. 2014, 46, 1079-1085

25. Shi, L.; Hou, A.G.; Chen, L.Y.; Wang, Z.F.Polymer Composites. 2015, 36, 1280-1285

26. Bowei Xu.;Xiaofu Wu.;Haibo Li.; Hui Tong.;Lixiang Wang. Macromolecules. 2011, 44, 5089-5092

27. Mojtaba Mahyari. Inter. J. Env. Anal.Chem. 2016, 96, 1455-1468

28. Srinivasan, K.; Stalin, T.;Shanmugapriya, A.; Sivakumar, K. J. Mol. Str. 2013, 1036, 494-504

29. Manisankar, P.; Vedhi, C.; Selvanathan, G.; Arumugam, P. Microchimica Acta, 2008, 163, 289-295

30. Suresh, E.; Sunaram, K.; Kavitha, B.; Senthil Kumar, N. International Journal of Chemical and Pharmaceutical Sciences. 2016,7(2), 42-47. 